
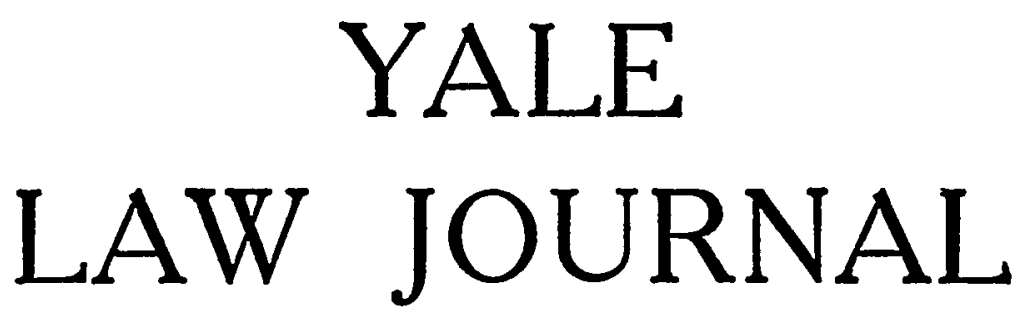

\begin{tabular}{lll}
\hline \hline Vol. XXVII & NOVEMBER, 1917 & No. 1 \\
\hline \hline
\end{tabular}

\title{
THE LAW AS AN EXPRESSION OF COMMUNITY IDEALS AND THE LAWMAKING FUNCTIONS OF COURTS
}

\author{
JOHN E. YOUNG \\ Supreme Court of New Hampshire
}

If we are to study law intelligently, we must not only understand what it is and its office in the social scheme, but also the forces which both immediately and mediately dominate its development. I shall assume for the purposes of this paper that each of the autonomic groups into which the human race is divided is an entity with a mind of its own which evolves ideals and makes laws to effectuate them, and creates the corporation known as the state to enforce its laws. In other words, I shall attempt to show that community ideals are emergent facts incident to the development of every community; that laws are the tools a community makes to effectuate its ideals, and the state, a corporation it creates to use these tools; or that laws and the state are the means a community employs to effectuate its ideals.

The term community has several meanings, but is sometimes used as synonymous with autonomic group; that is the sense in which I shall use it. The term state also has several meanings, but as I shall use it, it is synonymous with the governing entity of an autonomic group. In other words, as I use the term community, one of the autonomic groups into which the race is divided is intended; and as I use the term state, the governing entity of such a group is intended. By individual ideals, as I shall use that term, the opinions an individual forms as to what 
he should do or omit to promote his own welfare and that of the human race is intended; and by community ideals, the opinions a community forms as to what it should do to promote its welfare and that of the individuals of whom it is composed. In other words, by community ideals, as I use that term, are intended the concepts that go to make up public opinion.

Notwithstanding it will be necessary to consider the evolution of the human race in order to understand how ideals are evolved, and why laws are made to effectuate them, I shall not consider the force which dominates its evolution, except in so far as may be necessary to show that that force, whatever it may be, is not the one which immediately dominates the making of laws.

There is a difference of opinion as to whether laws affect persons and property, or persons only; but I shall assume that they are made, and that while they affect property, they affect it through individuals; or that all laws are commands delimiting what those subject to them must do to avoid civil or criminal liability.

The term law has no technical meaning; consequently it will be necessary to define that term before $I$ attempt to show what law is, or its office in the social scheme.

A definition, to be of any practical value, must be broad enough to include every feature common to all the rules of all the laws and systems of law that have been, are, or ever will be in force, and narrow enough to exclude all features peculiar to particular laws and systems of law. It is common knowledge that there are innumerable laws and systems of law, and that the rules of no two are identical. In fact, every system commands acts to be done that the other systems forbid. It is also common knowledge that we have the laws of grammar, of baseball, of billiards, etc., in addition to juridical law; also, that some of the rules of all the various systems are continually breaking down, and new rules being substituted for them.

The question, therefore, that naturally arises when these things are considered, is whether there are any features common to all the rules of all these various systems-in other words, whether there are any earmarks by which a law may always be known; or whether there is anything common to a rule which makes it a felony punishable with death to teach a servant to read, and one which makes it a misdemeanor to employ a servant who cannot read.

Many definitions of law can be found in the books-nearly as many, in fact, as persons who have considered the question. 
One reason for this is because the term law has no technical meaning. We speak of the laws of nature, of juridical law, and of the laws of grammar, etc. This discussion, however, is limited to a consideration of juridical law; and while that narrows its scope, it is still true that the term law has no accepted meaning. As that term is sometimes used, its makers are intended, as when we speak of the end, purpose or problem of law.

If laws are made, that is, if they are not facts in the sense in which the so-called laws of nature are facts, what must be intended when we speak of the purpose of a law is the end its makers had in view when it was enacted. ${ }^{1}$

By law, as that term is sometimes used, the standard of justice, or the yardstick to determine right from wrong, is intended; and an attempt to define it resolves itself into an attempt to define the standard of justice.

I think that that standard is subjective, or to be found in the mind of the lawmakers; but many, perhaps the majority, think that it is objective, or to be found outside of the consciousness of the lawmaker. In other words, I think the yardstick to determine right from wrong for each of the communities into which the race is divided is to be found in its consciousness. If this view is sound, the time will come when the standard of justice will be found in the consciousness of the race; for the time is coming when all the different communities will be fused into one community, and when that time comes, community ideals will be the ideals of the human race. In short, in my view of the matter, the standard that is in fact applied to determine right from wrong is to be found in public opinion, whether the community that evolves it is a savage tribe or the race as a whole. While public opinion is the practical standard of justice, the ideal standard is the concept that those acts and those only that tend to promote the welfare of the race as distinguished from the welfare of particular communities are right, just and equitable. $^{2}$ While this is my view of both the ideal and the practical yardstick to determine right from wrong, the majority believe that the standard is objective, or that it is to be found somewhere in space rather than in the consciousness of the individual, of the community or of the human race. If we are to understand what law is and its office in the social scheme, it

\footnotetext{
${ }^{2}$ Professor Roscoe Pound, The End of Law (Igr4) 27 HaRv. L. Rev. 195.

2 Small, General Sociology (Ig05) 657-683.
} 
will be necessary to determine which of these views is sound; that is, whether the standard is objective or subjective; but in order to save repetition, I shall consider that question when I am considering whether there are any features common either to the source or to the content of all laws and systems of law.

When law is used in the sense of the standard of justice, it is said that it "is the standard of conduct which in consequence of the inner impulse that urges men toward a reasonable form of life, emanates from the whole, and is forced upon the individual" ; 3 or that it is "the objective co-ordination of possible acts among men, according to an ethical principle which determines them and prevents their interference."

Some of those who believe the standard of justice is objective think that it is to be found in individual liberty, or that only those laws are just which tend to promote the liberty of the individual at the expense of the community; in other words, that law is intended to effectuate individualism. Others think law is intended to hold society together; that the end of law is to find a place for everyone and to keep him in his place, and that those laws and those only that have that effect are just. Others think the standard is to be found in equality, and that those laws and those only that tend to make everyone equal before the law are just. ${ }^{5}$ Others think the test to determine whether an act is just is to inquire whether it will promote the welfare of the race as distinguished from the welfare of particular individuals, or classes of individuals. ${ }^{\circ}$ There are those who find the standard of justice in what the Germans know as "Kultur," and they think that those laws only are just that tend "to secure and increase the progress of culture by so moulding rights and the universal cultural values which it protects that the hampering elements are removed and the improved tendencies supported and strengthened." In short, there are as many objective standards of justice as persons who believe in such a standard.

\footnotetext{
Orrin N. Carter, Introd. to Kohler, Philosophy of Law (Igr4) xxxvii.

'Del Vecchio, The Formal Bases of Law (IgI4) 218.

- Demogue, Analysis of Fundamental Notions, Modern French Legal Philosophy (rg16) 37 I.

Small, op. cit. 680-685.

'Kohler, Philosophy of Law (IgI4) 60.
} 
As the term law is commonly used, the system of rules in force in a particular country delimiting what its citizens must do to avoid civil and criminal liability is intended. When used in this sense, law is said to be the "body of rules and principles in accordance with which justice is administered by the authority of the state" ; $;$ and a definition of law usually assumes the form of a definition of one of these rules. They are said to be rules for the delimitation of interests; ${ }^{*}$ of wills; and sometimes of both interests and wills; sometimes rules for the protection of interests; and when we come to the cases, they are said to be rules of civil conduct that the state will enforce $;^{10}$ or more generally, rules the state may enforce. ${ }^{11}$ To some, these rules are as unchangeable as the laws of the Medes and Persians. Others recognize that they change to keep pace with the changes in their makers' ideals. Still running through much that is to be found in the books is the idea that there is something in law, "a core" or "inner nerve," as it is sometimes called, that causes it to develop in a way to promote the well-being of the race. As will be shown more fully later, this is putting the cart before the horse, or putting the thing that is made in the place of its makers. There is a force either in or outside of humanity that dominates its evolution or causes it to develop in such a way that the number of those who share in the good things of life is constantly increasing, while law is merely one of the things communities employ to bring this about.

If all the definitions of law to be found in the books are accurate from their authors' point of view, they afford but little help in our search for earmarks common to all rules of law. There are no features common to the definitions of law when it is used in the sense of the standard of justice, and when it is used in the sense of a system of rules the state will enforce; and the only feature common to the definitions of the second class is that a rule of law is a rule of civil conduct; intending by that a rule delimiting what those subject to it must do to avoid liability.

To say that a law is a rule of civil conduct is but little more helpful to one in search for the earmarks by which a law may

\footnotetext{
- Pound, loc. cit.

- Korkunov, General Theory of Law (I909) 79.

"I Blackstone, Comm. *44.

${ }^{11} 25$ Cyc. 163, 18 A. \& E. Ency. Law 569, 5 Words \& Phrases 4014.
} 
always be known, than to say iron is hard to one who is trying to learn how iron may be known. In other words, such a definition merely changes the question from what features are common to all rules of law, to what features are common to all rules of civil conduct. While most persons will agree that law is intended to promote justice, there is, as has already appeared, no consensus of opinion as to the test to determine when a law is just, or as to the yardstick to determine right from wrong. While I think the test is to be found in the opinion of the majority, many think it is to be found outside of human experience. I shall attempt, however, to show that this standard is subjective, or to be found in the consciousness of the lawmakers, and that those laws and those only that tend to promote the welfare of the community as distinguished from that of particular individuals are just. If this view is sound, there are as many standards and sources of justice as systems of law; for in this view of the matter, each community evolves its own ideals and makes laws to effectuate them. As each community evolves its own ideals, each must have its own standard of right and wrong; for that standard, in so far as any particular community is concerned, is equal to the sum of its ideals. If, however, the standard were objective, every community would have the same standard of right and wrong; for if it were objective it would be a fact, in the same way gravity is a fact, that could be found, and the results it would produce in a given situation could be discovered and stated in the same way the effects that heat, light or sound will produce have been discovered and stated. In short, if the standard of justice is objective, it can be discovered, and the effects it will produce in any given situation can be stated with approximate accuracy, not only by judges, but by anyone who possesses the necessary skill and will take the trouble to make the necessary investigation. All fair-minded men will, I think, agree that that cannot be done, for if it could, public ideals would not change, and each generation would think the same thoughts as all those which preceded it. And it would be true that law is intended to find a place for everyone and to keep him in it; or rather, that it is intended to hold society together in the same way gravity holds the universe together. In short, unless mind is as inert as matter, there can be no objective standard of justice. Since this is so, a definition of law cannot include any features peculiar to the content of all rules of law; for if laws are made to effectuate their makers' 
ideals, they are simply a means to an end, or. tools invented to effectuate their makers' ideals. Since no two communities have, or for that matter can have, the same ideals, no two can have the same standard of justice or the same yardstick to determine right from wrong; for as we have seen, such a yardstick is composed of its makers' ideals; and it necessarily follows that no two systems of law can have the same content. The question, therefore, of whether there are any features common to all rules of law, or any earmarks by which such rules may always be known, resolves itself into one of whether there are any features common to the form or to the purpose of all rules of law. If the standard of justice is subjective, it necessarily follows that laws are made. And if they are made, it requires no argument to show that they are made to effectuate their makers' purpose. This would be true if the standard of justice were objective; but in that case, the force which dominates the making of law would be the same as the one which dominates the evolution of the race, and consequently the purpose of law would be the purpose of the Creator. It is true that laws are intended to effectuate their makers' purpose, whether they are of divine origin, or made by a community or an individual; for the mind of a community is so far like the mind of an individual that the only force which can induce it to give the command necessary to put itself in motion is a desire to satisfy one of its needs; and as will appear more fully later, such a desire is the only force that can induce an individual to give the command necessary to put his muscles in motion.

In short, the standard of justice is subjective, and all laws are not only made, but are made to effectuate their makers' ideals ; that is, they are simply a means to an end.12

As has already appeared, all laws, in the final analysis, are commands; and it is obvious that they must assume that form if they are to effectuate their makers' ideals, for the only way in which that can be done is for the lawmakers to delimit just what those subject to the law shall do in a given situation. In other words, the only way in which a community can effectuate its ideals is by limiting individual freedom of action.

There are, therefore, three features common to all laws: they are rules that are made; they are made to effectuate their

\footnotetext{
${ }^{2}$ Von Thering, Law as a Means to an End (IgI3) liv.
} 
makers' purpose-that is, they are the tools he invents to effectuate his purpose; and they limit individual freedom of action. As it seems to me, these features are common to all rules of law, and are the only features common to all laws and systems of law; that is, to the laws of grammar, of baseball, of billiards, etc., to say nothing of moral and of juridical law. You cannot think of a law that was not made; nor of one that is not a tool; that is, of one that was not made to effectuate its makers' ideals; nor of one that does not attempt to do that by limiting individual freedom of action, or by delimiting what those subject to it shall do in a given situation.

It is probably true that in the beginning these were all the features common to the rules of juridical law, but for countless centuries all such rules have had another common feature: that is, they have been rules the state may enforce. If laws are made either by individuals or by communities, it is obvious that they cannot effectuate their makers' purpose in and of themselves; for if they are made, they are not a force like gravity, but simply tools, and do not differ from other tools-for example, a blacksmith's hammer-in so far as the capacity to effectuate their makers' purpose is concerned. The hammer, in and of itself, is an inert mass, but the smith uses it to shape iron, or to effectuate his ideals. Force, however, is necessary to effectuate them, and as there is no force in the hammer, the smith applies force to it.

In the same way, there must be force behind laws if they are to effectuate their makers' ideals. The making of laws, therefore, is but one step in the process of effectuating ideals. To do that, laws must be both made and enforced. In other words, if a community is to effectuate its ideals, it must both delimit what its members shall do or omit in a given situation, and create an entity that will punish those who fail to do or omit the things the law commands; or it must compel them to compensate one who is injured or damaged for all the loss he sustains because of their illegal acts. By this is not intended that force enters into the composition of a rule of law. ${ }^{13}$ What is intended is that force is one of the things necessary to effectuate ideals. Since this is so, when the entity which evolves ideals is a community, it must both make the laws and give some individual or corporation the power to enforce them, if it is to effectuate its ideals.

\footnotetext{
${ }^{13}$ Korkunov, op. cit. 96.
} 
All the rules of juridical law have, therefore, four common features: (I) they are made by a community; (2) to effectuate their makers' ideals; that is, they are the tools it invents to effectuate its ideals; (3) they limit individual freedom of action; that is, they delimit what those subject to them shall do in a given situation; and (4) they are rules that the state may enforce. The test, therefore, to determine whether a rule is a law in a particular community is to ask (I) if the community made it. (2) If it did, why it made it. (3) If it was made to effectuate one of the makers' ideals, how it attempts to accomplish that purpose; and (4) whether it is a rule the state may enforce, intending by that to punish those who neglect or refuse to do or omit the things it commands, or else compel them to compensate one who is injured or damaged by this failure to obey the law for all the loss he sustains because of their illegal acts.

If, however, the standard is objective, a law is a rule limiting individual freedom of action that the state may enforce. In other words, if there is such a standard, Blackstone's definition of law as a rule of civil conduct the state will enforce is both concise and accurate; for while it is true that laws are intended to effectuate their makers' purpose even if they are parts of creation, no definition of law that includes a statement of that purpose can be made that will be accepted by any considerable number of people; for while there are many who believe there is an objective standard of justice, there are no two who can agree as to just what that standard is.

This brings us to the question of the force which dominates the making of laws, and I shall attempt to show that it is the needs of a community as distinguished from the needs of the individuals who compose it. If the standard of justice is subjective; that is, if laws are made by either individuals or communities, we must begin the study of law with a study of the evolution of the human race. While it was once thought that the individual was the unit into which the race was originally divided, almost everyone now concedes that the unit was the social group. In short, it is now the orthodox view that there never has been a time when men either could or did live independently of their fellows, ${ }^{14}$ or when each individual either could or did live by his own unaided efforts. In fact, there is something innate in every normal human being which compels him

"Berolzheimer, The World's Legal Philosophies (1912) 216. 
to become a member of some social group. The elements which make up that something consist in part, at least, of sentiment, passions, physical and psychical wants, and a desire for the society of others, as well as for help and protection. Although that something is composed of these elements, the combination of them is not the same in any two individuals; still, some one or some combination of them dominates every normal human being and compels him to become a member of a social group. This was as true when time began as it is to-day. In fact, there never was and never will be a time when social groups were not and will not be absolutely essential, not only to the mental evolution, but to the very existence of the human race.

Since such groups are composed of individuals each with a mind and purpose of his own, it is obvious that law is essential to the existence of such groups. In other words, it is selfevident that a group cannot exist without law, intending by law, limitations on individual freedom of action; for if every one were to do just as he pleased, if no one respected the rights of others, we should not have groups of men associated together for mutual help and protection, but a situation in which each man was acting for himself, or a situation in which every man was against every other man.

In other words, if it were not for law we should have "a war of all against all," or a situation in which each man was constantly trying to overreach all the others. Law, therefore, is absolutely essential to the existence of a community, and communities are equally essential to the existence of the race. Since individuals cannot exist without communities, and communities cannot exist without law, it follows that both law and the social group are as old as the race. This shows that the needs of a community are the forces which dominate the making of laws, and the needs of individuals are the forces which dominate the forming of communities. We can get a fairly accurate view of a social group in the first throes of evolving ideals and inventing laws to effectuate them by studying young children. Such a study will show that when a child is born he is helpless, and that as he develops, he looks on those who care for him in something the same way the ordinary man looks on God. Experience, however, teaches him that his protectors can and do make mistakes, and that he must decide for himself what he ought to do or leave undone in a given situation; and there comes a time in the life of all normal children when they seek the society of 
others of the same mental development, and form more or less compact groups. When such a group is first formed, none of the children have the slightest idea of law; but gradually the group evolves ideals and customs to effectuate them, and the dullest child soon learns that he must comply with these customs if he wishes to remain a member of the group. This shows us both how and why laws are made, as well as who makes them. The child study is also useful when we are considering the evolution of the state and its purpose in the social scheme. A group of children always develops around a leader who dominates its activities to a greater or less extent. Although the group begins to evolve ideals and customs to effectuate them as soon as it is formed, none of the children at that time understand the purpose of customs or why they should obey them. All they know is that they must obey them if they wish to remain members of the group. In time, however, they realize that the office of customs is to effectuate group ideals, and that customs are a delusion and a snare, or that they benefit principally those who intend to disobey them, unless the group enforces them. When the group finally grasps that idea, the leader is usually able to make use of it to increase his power. In other words, the leader is able to exercise authority over the group when it is first formed because of his real or fancied superiority; but when group consciousness develops, the idea that he represents the group and should be obeyed for that reason also develops and has a tendency to put him above the law. Since the mind of a child passes through about the same phases in the course of its evolution that the human mind has passed through, it is probable that the state developed in something the same way, or that each of the groups into which the race was divided developed around a leader who exercised more or less authority over it. As group consciousness developed, the leader made use of it to increase his power, which in time became autocratic.

It is impossible, however, to say that the analogy holds; all that can be said is that we have no traditions-much less any record-of a community with laws but without a state to enforce them. It is possible, however, to form a fairly definite idea of the predicament of such a community, for we have a complete system of international law in so far as familiar situations are concerned, but no machinery to enforce its rules; so, when a state commits any serious breach of international law, the community or communities that are aggrieved fight, as they say, 
to enforce the law. In other words, in such cases, that usually happens which happened long, long ago when one member of a social group was injured by another's breach of a group custom.

Although we have no record of a time when there were communities with laws but without a state to enforce them, there was a time not so very long ago when the machinery for enforcing laws was woefully inefficient in so far as the communities from which we are descended are concerned. The earliest traditions relate to a time when the family was the autonomic group, and at that time, the head of the family exercised more or less authority over its members; but after tribes were evolved from the family, the tribe usually administered its affairs in an assembly composed of the whole body of free men. This is true in so far as the Germans from whom we are descended are concerned, and is probably true of the whole Aryan race. Each of these tribes had a chief who presided over its assembly and exercised more or less authority over tribal affairs. At first the office seems to have been personal; but gradually the chief was able to increase his power, and in time the office became hereditary and he became a king resting his right to rule on the will of God-not on the will of his people. When absolutism had done its work, the people tired of their kings and put them under the law; and in that way the modern constitutional state was evolved to do some of the things kings had done, and such other things as the community which made it thought would promote the community's well-being. In other words, a modern constitutional state is a corporation created by a community to administer its affairs. This is true notwithstanding most European states were evolved from the original group through the family, tribe and kingdom; for, while the community has the right to limit individual freedom of action in so far as that is necessary to effectuate its well-being, no man has or can have that right, if men are equal, except in so far as he acts for the community.

All states, therefore, no matter when or how they were formed, are corporations with such powers and such powers only as their creators gave them. To illustrate my meaning, the people who created the British monarchy vested the supreme legislative power in Parliament; but those who created the United States of America retained that power in their own hands.

If, therefore, we are to understand what a state can and cannot do, we must remember that while the community is 
omnipotent, the state created by it can only make such laws as the community has authorized the state to make, and that the state cannot enact laws to effectuate a public ideal unless the community has authorized it to make them. The failure to realize this fact lies at the root of most of the honest criticism to which the courts have been subjected for holding statutes unconstitutional. It is true that in some cases these statutes were calculated to promote the well-being of the human race, and to promote it in the way the community approved; but in most cases it is also true that these statutes were in conflict with some one or more of the provisions of the constitution. In other words, while some one was to blame for the failure of some of these statutes, in most cases that some one was the community. In short, it is the community and not the state in which the power to make laws is vested. Since this is so, the common saying that if the state were destroyed, the law would perish, is in no sense true. The history of Europe since the sixth century makes this clear; for at that time the Roman Empire of the West was overthrown, but the civil law is still the common law in all or nearly all parts of Europe where those who evolved the ideals it was made to effectuate resided.

The history of the United States tends to the same conclusion, for the state perished when the thirteen colonies separated from Great Britain; but the only noticeable effect its destruction had, in so far as law was concerned, was that there was no machinery to enforce it until the colonies created new corporations for that purpose. The law and the state, therefore, are at one and the same time the tools the community makes to effectuate its ideals, and the things without which it cannot exist.

In short, as will appear more fully later, public ideals are emergent facts incident to the evolution of every community, while the law and the state are the means it employs to effectuate them. While law is made by a community and not by individuals, it is in a sense true that it is something a man carries with him wherever he goes. What he carries, however, are the ideals the law is intended to effectuate; and that explains why a colony always adopts the laws of the fatherland as its laws; for they are intended not only to effectuate the colony's ideals, but to effectuate them in the way it approves. That is all that is intended when it is said that our Anglo-Saxon ancestors brought their law with them to Britain, or that our British ancestors brought their law with them to America. 
Massachusetts furnishes a good illustration of what I have in mind. The early settlers hated English law and everything that had to do with it with a hate that was both deep and cordial; but they were Englishmen with English ideals, and notwithstanding they adopted the law of Moses as their law, the form it assumed in their hands was that of the law of England, except in so far as religious matters were concerned. The reason for this is obvious: English law was, and the divine law was not, adapted to the industrial conditions that prevailed in Massachusetts. In other words, English law was adapted to their needs, and it was as natural for them to adopt it as their law as it was for them to use the English language.

Since a law is made by a community to effectuate its ideals, the problem for every community is, always has been and always will be to determine just what limitations it should impose on individual freedom of action to promote its well-being; and it may be useful to see how our Celtic-Anglo-Saxon ancestors solved that problem. History shows that they were accustomed to administer all their public affairs in local assemblies in many ways like a New England town meeting except that these assemblies exercised judicial as well as legislative and administrative functions. ${ }^{15}$ When such an assembly was exercising its judicial functions, the test it employed to determine the legality of the act complained of was to inquire whether it was customary. That, as I shall attempt to show, was but another. way of inquiring whether it was reasonable, or one of which they approved; for the issue of its legality was not decided by written rules, but by a vote of a majority of the suitors-or as we should say, those qualified to vote in that precinct-present and voting.

It is common knowledge that we are apt to think of the things we approve as customary. In short, with most men, inquiring whether an act is customary is but another way of inquiring whether it meets with their approval, and that was more nearly true a thousand years ago than it is to-day.

The test, therefore, that our ancestors in fact applied to determine the legality of an act was to inquire whether it was reasonable. In other words, about the only limitation our Celtic-Anglo-Saxon ancestors imposed on individual freedom of action was that of not doing anything that would injure or

${ }^{15}$ Thayer, Evidence (I898) 8. 
damage others unreasonably; or stated positively, that of doing those things and those only of which the majority approve. The test, therefore, that our ancestors in fact applied to determine whether one who was injured by the acts of others could recover, was to inquire whether the act which injured him was reasonable or one of which they approved; and the verdict depended on how the majority answered that question. It is clear that, if laws are intended to effectuate public ideals, that is the test which should be applied to determine the legality of an act, for public ideals are the ideals of the majority. In other words, all acts the majority approve either are or should be legal, if the needs of the community are the forces that dominate. the making of laws; and, that they are, is the foundation on which government by the people rests. Any act of which a majority approves is, therefore, customary, reasonable, right, just and equitable regardless of the effect it may have on individuals; and it follows that any rule the majority approves is just and reasonable regardless of the limitations it imposes on individual freedom of action. The law of every community, therefore, should consist of the general rule that it is everyone's duty to do those things, and those only, which the majority approve, and of a more or less complete body of special rules intended to apply the general rule to familiar situations.

The questions of how the needs of the community produce statutes, and how the rules of the common law are evolved, remain to be considered. I shall, however, consider them separately; for the agency the community employs to make statutes is not the same as the one which formulates the rules of the common law, and the knowledge of how statutes are made is apt to be misleading when we are studying the evolution of the common law. Since statutes are made by communities to effectuate their ideals, we must begin our study of how they are made with the study of the evolution of public ideals. That necessitates a study of the evolution of individual ideals, for the evolution of such an ideal is the first step in the evolution of all public ideals. In considering this question, it will be helpful to remember that while a community is an entity with a mind of its own, ${ }^{18}$ it is composed of entities each of whom has a mind separate and distinct from the general mind, and more or less well-developed reasoning faculties; and each of these entities

\footnotetext{
${ }^{10}$ Small, op. cit. I33.
} 
not only can, but is accustomed to, form opinions of his own as to the things he should do and as to how he should do them to promote his well-being and that of the community. It is as natural for men to form such opinions as it is to breathe, and all normal human beings at some time in their lives form more or less definite opinions in respect to such matters. In fact, so far as familiar situations are concerned, most men form very definite opinions as to what they should do or omit if they are to prosper. Most persons not only have their own opinions as to such matters, but also impose such limitations on themselves as they think are necessary to make their lives square with their ideals. The term ideals, as commonly used, includes a part only of the opinions a person forms as to what he should do or omit to promote his welfare and that of the community; but as I use that term, it includes all the opinions he forms as to such matters; that is, the opinions he forms as to economic and political as well as ethical questions. It follows that moral law, as $I$ use the term, includes all the limitations an individual imposes on himself; that is, rules to determine how to vote and what to eat, as well as ethical rules. To understand how ideals are evolved, we must remember that the mind of an individual is so constituted that any want, either physical or psychical, that he may feel excites in him a desire to satisfy it; it follows that a person's desires increase as his wants increase. In other words, every normal human being possesses or is possessed by a constantly changing number of wants, some physical, others psychical; some selfish, others altruistic; each with the power to excite a desire to satisfy it. Such a desire is said to be a natural force, or a force that acts on mind in something the same way gravity acts on matter. In fact, it is said that such a desire is the only force that can produce mental activity, or the only force that can induce a man to give the command necessary to put his muscles in motion.

Since it is impossible for a man to satisfy all his wants at the same time, each of them is continually struggling to control his mind, and the opinions he forms as the net result of this struggle are what $I$ have called individual ideals.

It is common knowledge that a person's ideals change not only with a change in his environment, but from various other causes, the trend of this change, so far as any particular ideal is concerned, depending largely on the relative strength of his desires. As no two persons have exactly the same environment, 
or place exactly the same value on any given want, so no two have exactly the same ideals. By that is not intended that no two persons have any common ideals. The exact opposite is the truth, for there are no two men but have some ideals in common, and the great majority of the community entertain most of the ideals that make up public opinion. Notwithstanding everyone shares most of his ideals with a majority of the community, still every normal human being has some ideals peculiar to himself, and others that he shares with various groups each of which consists of less than a majority of the community. While individual ideals are evolved in this way, no individual evolves all his ideals for himself. In fact, the average man absorbs most of his ideals ready-made; that is, he selects such of the ideals of others as appeal to him, and adopts them as his own.

As has already appeared, all public ideals are evolved from individual ideals; but when we are studying the evolution of public ideals it is necessary to remember that the community is an entity with a mind separate and distinct from the minds of the individuals who compose it. It is impossible for me to say just what this entity is, ${ }^{17}$ but I think that whenever two or more persons associate themselves together for any purpose, their minds interpenetrate in such a way as to form a common mind or a community mind in so far as the common purpose is concerned. ${ }^{18}$

In other words, while I cannot show just what the community mind is, or for that matter, just what the human mind is, I shall assume for the purpose of this discussion that there is such an entity, or that, while the individuals who compose a community are constantly changing, the minds of the members for the time being constitute an entity in something the same way the cellsthe living organisms of which the body is composed-constitute the entity we know as the body; that is, each cell is at one and the same time a separate organism and a constituent part of the organism we know as the body; in the same way, the mind of an individual is at one and the same time a distinct entity, and a constituent part of the entity that $I$ have called the community mind..$^{19}$

\footnotetext{
"Small, op. cit. 133 .

${ }^{28}$ Korkunov, op. cit. 276.

${ }^{10}$ Miraglia, Comparative Legal Philosophy (IgI2) 370, 428.
} 
The fact that this entity cannot be apprehended by our senses has no more and no less tendency to prove that there is no such thing, than the fact that the human mind cannot be apprehended in that way has to prove that it does not exist. Everyone will, I think, agree that there is such a thing as the human mind, and that it dominates the activities of every normal individual; and I think that it is as certain that the community mind, the common mind, the general mind or public opinioncall it what you will-dominates the activities of the community and is the final arbiter of right and wrong.

It will be enough for our purpose, however, to say that every community has a mind of its own, and that it is capable of evolving ideals. Although community ideals are the ideals of a majority of its members, they do not equal the sum of the ideals of all its members; for while the community mind does not contain any ideals not to be found in the mind of a majority of its members, the mind of every normal human being contains ideals not to be found in the community mind.

In fact, the community mind is in some ways like a composite photograph of the minds of all its members, for it reflects the ideals common to a.majority, and not those peculiar to a minority of its members.

It helps but little, however, to say that the ideals the community mind reflects are those common to a majority of the community, for the struggle from which public ideals emerge is more complex and more difficult to understand than the one from which individual ideals emerge. While it is true that the desire which the needs of a community excite is the force which dominates the making of law, this desire is excited in individuals in many different ways. In some it is excited by selfishness, in others by altruism; in some by prejudice, in others by knowledge; in some by hate, in others by love; in some by passion, in others by experience; in some by one thing and in others by another. In fact, no one can say, so far as a given public ideal is concerned, which of these things moved the minds of the different members of the community. All that can be said is that one of these things or some combination of them dominated the minds of the majority. As we have seen, both individual and community ideals emerge from a struggle; but in one case, the struggle is carried on in the minds of a community, and in the other, in the mind of an individual. In one case the contestants are the wants, and in the other, the 
ideals of individuals. In one, the emergent facts are community, and in the other, individual ideals. As has already appeared, community ideals make up the content of the community mind, or constitute the concepts that make up public opinion; and it will help us to understand what that is to remember that the struggle from which these concepts emerge began at the time the first social group was formed; that only a few of these concepts were evolved by the community as it existed at any given time; and that while some of them are as old as humanity, others were evolved but yesterday, and still others will be evolved to-morrow.

In other words, it will help us to understand what public opinion is to remember that while an individual is mortal, a community is immortal; or that, while the opinions of an individual begin and end with him, except in so far as he is able to impose them on others, public opinion had no beginning and will have no ending. ${ }^{20}$ Although the community is immortal, its ideals change; and while this change may seem slow when measured by the changes that take place in individual ideals, it never ceases.

By this is not intended that the concepts of which it is composed do not continue as public ideals for an appreciable length of time; what is intended is that there is never a time when an ideal is not breaking down and new ideals being evolved from so much of the old ideal as is vital. The direction of this change, so far as any particular ideal is concerned, depends in part on the same facts that control the change in individual ideals, and in part on the relative strength of those who entertain the conflicting ideals.

Although this accounts in a general way for the change that is continually taking place in public ideals, it will, perhaps, be useful to consider this change a little more in detail. Something either physical or psychical in a person's environment reacts on him and causes him to re-examine the foundations on which one of his ideals rests. The usual result of such a re-examination is a new ideal. If this ideal appeals to others, there may at first be as many opinions in respect to it as persons who consider it; but in the end, the view of some individual or group of individuals prevails and transmutes what had been the ideal of

\footnotetext{
${ }^{20}$ Small, op. cit. I39.
} 
individuals into one of the concepts that go to make up public opinion.

It will be helpful to keep in mind what moral law is, and the part it plays in the development of law. As has already appeared, moral law is the law of the individual, or the means he employs to effectuate his ideals, while juridical law is the law of the community, or the means it employs to effectuate its ideals. It is necessary, in order to get an accurate idea of the similarities and the dissimilarities in the process by which the two classes of ideals are evolved, and of the forces which immediately dominate their evolution, together with the parts moral and juridical laws play in the social scheme, to keep constantly in mind the fact that a community is made up of a constantly changing number of individuals each of whom has a mind of his own and is constantly trying to satisfy his wants or to improve his condition; while an individual's mentality is made up of a constantly changing number of wants each of which is continually struggling to induce him to satisfy it. The community cannot permit one of its members to act in a given way without limiting to some extent the freedom of action of all its other members, and an individual cannot permit one of his wants to dominate his activities without limiting to some extent his capacity to satisfy his other wants. The problem for both the community and the individual is to regulate the activities of the entities of which they are composed in such a way that each shall have the greatest possible freedom of action consistent with the well-being of all the entities of which it, or he is composed.

Both attempt to solve this problem by imposing limitations on freedom of action. The community imposes them on its members, while the individual imposes them on his wants. To determine what limitation should be imposed, the yardstick employed by both is composed of what I have called ideals.

In other words, the community attempts to solve this problem by delimiting what it thinks each of its members should do or omit in all the different situations in which they may find themselves in the pursuit of business or pleasure, while the individual attempts to solve it by delimiting what he should do or omit under all circumstances. In short, juridical law plays the same part in the life of a community that moral law plays in the life of an individual; that is, public opinion does for a community what conscience does for an individual. 
With these facts in mind, there is no difficulty in understanding how statutes are made. When a particular ideal becomes a public ideal, it excites a desire on the part of the community to effectuate it, and when this desire becomes strong enough, the community elects legislators who make the necessary laws.

While this shows how and why statutes are made, it also shows that the rules of international law are not so much laws as customs; intending by that, rules the majority think everyone should obey; or perhaps it is more accurate to say of these rules that they are emergent facts incident to the evolution of the race as a whole, for the only way in which they can be enforced is for each community to enforce them for itself. These rules will never be laws, except in the sense in which the laws of grammar, of baseball, etc., are laws, until a majority of the race realize that their first duty is to the race rather than to the particular community to which they owe allegiance, as for example to England, France, Germany or Russia; but if and when they finally realize that fact, they will have no difficulty in finding a way to make the laws necessary to effectuate their ideals and to create a state to enforce them. In other words, while the rules of international law are laws in the sense in which the rules of grammar are laws, they are powerless to effectuate the purpose for which they were made except in so far as the different communities wish to obey them. In fact, they are laws in the sense in which the rules of moral law are laws, but not in the sense in which the rules of juridical law are laws; for the community which makes them has not created an entity with power to enforce them, and such an entity cannot be created until a majority of the race realize that they are men-not Chinamen, Englishmen, Frenchmen, Russians, Turks or Germans; that nothing is really for the advantage of China, etc., that is not calculated to promote the welfare of the race as a whole; and that those laws and those only are right, just and equitable which are intended to promote the welfare of humanity as distinguished from the welfare of particular communities.

While the knowledge that public ideals are emergent facts incident to the evolution of all communities, and that law is simply a means to effectuate them, enables us to understand how and why statutes are made, it is of little or no help in enabling us to understand how the rules of the common law are made. In fact, this knowledge is positively misleading when we are trying to solve that problem; for after all is said, but a part 
of these rules are true laws-that is, rules intended to effectuate public ideals, and to effectuate them in the way the public approve. In some cases the ideals they are intended to effectuate never were, and in others they have ceased to be, public ideals.

It will help us to understand what the rules of the common law are and how they were evolved to keep in mind the fact that the term law has no technical meaning. As it is sometimes used, natural law, or what was commonly supposed in the eighteenth and nineteenth centuries to be natural law, is intended. That is the sense in which it is used when it is said that it is an "unwritten" law, or what the court has in mind when it says that a case "must be decided on principle," or that it "found" the rule it applied to determine the rights of the parties. As has already appeared, this theory of law depends for its validity on the proposition that the standard of justice is objective.

By the common law is sometimes intended those rules that can be deduced from cases decided in the king's courts. While this; as will appear more fully later, is the original meaning of that term, its use in that sense is unusual at the present time.

As commonly used, that term includes both of these meanings and something more; that something more comprehends all rules that can be deduced from acts of Parliament and of the provincial legislature enacted before 1776 . When used in this sense, the common law includes not only all rules that can be deduced from cases decided and statutes enacted before $I 776$, but also the doctrine that it is the duty of the court to "find" a new rule whenever a situation arises in which no statute and no formulated rule of the common law is applicable.

While it is often said that the common law is an unwritten law, by that is not intended that its rules have not been reduced to writing; what is intended is that they were not formulated by Parliament or by the provincial legislature. In other words, to say that the common law is an unwritten law is literally true only so far as new rules are concerned.

One very real difficulty to those charged with the duty of administering it results from the fact there are more versions of it than of the civil law-as many, in fact, as there are writers engaged in elaborating it, and courts in administering it. The fact that all these courts and writers are constantly limiting some of their rules, or in some way qualifying or modifying them, or in overruling old and substituting new rules, accentuates this difficulty. 
It will be necessary to show what natural law is, or rather what it was supposed to be, in order to show that whatever the rules of the common law may be, they are not rules of natural law. By that term, as it is ordinarily used, something that delimits what everyone should do or omit in all places and under all circumstances is intended.

In other words, by natural law, as that term is ordinarily used, is intended a system of rules very like the laws of nature; or rules that are not so much commands which everyone subject to them should obey, as statements of the result that should follow in a given situation from the operation of natural forces.

That must have been the theory of those who elaborated the common law; that is, they must have thought of the rules they formulated as facts, for they say they "found" them, and it is obvious that neither a judge nor anyone else can "find" a rule that does not exist.

The court, therefore, must have thought of these rules as facts; and it is certain that if they are facts, anyone, whether a judge or not, who has the necessary skill and exercises sufficient diligence can "find" them and state them with approximate accuracy.

It is also clear that if they are facts, or if they can be "found," they are not laws in the sense in which statutes are laws, but rather laws in the sense in which the laws of heat, light and sound are laws. If the rules of the common law are laws in this sense, they control the development of the race. That seems to have been the belief of our fathers, for law was looked on by them not as a means to an end, but as an end that shaped the destiny of the race in the same way gravity shapes the course of a river. In other words, in the sixteenth, seventeenth, eighteenth and nineteenth centuries most persons thought of law as a system of rules of civil conduct that would work exact justice between man and man, not only in every situation in which a person had found himself, but in every situation in which he might find himself while time endured. ${ }^{21}$ This would be true not only for your experience and for my experience, but for every possible experience. These rules were thought of not as made by manthat is, as the result of human experience-but as something that existed before time began and would exist after time ceased to be. In short, these rules were thought of as parts of creation

"Iorkunov, op. cit. I30. 
and as something that would endure without change as long as the universe endured. ${ }^{22}$ Almost every one at that time seems to have believed in such a system, and what is more surprising, to have believed that the court and only the court could "find" those rules; and the court seems to have been of that opinion. ${ }^{23}$

In other words, there was a time when the court seems to have thought it was inspired, or that the rules it formulated were revealed to it. At that time, therefore, the common law was not thought of as consisting of rules that were made, and that sometimes did and sometimes did not work justice; but as a system as old as creation, composed of rules that not only always had, but that always would work exact justice between man and man; that is, as a system of specific rules as applicable to the needs of the men of the twentieth as to those of the sixteenth century. The fact these rules were often found to work injustice does not appear to have shaken men's faith in this theory of law. They seem to have thought this trouble was rather with the court than with the theory itself. As long as this view obtained, it did not seem quite as absurd to say the court "found" the rules of the common law as it does to-day, ${ }^{24}$ when many think that the only sense in which the standard of justice can be said to be objective is that it is to be found in the consciousness of the community, or that the test to determine whether a rule is right, just and equitable is to inquire whether it will promote the welfare of humanity as distinguished from the welfare of particular individuals.

It is true that many, possibly a majority, either believe in natural law, or else believe that an abstract concept of justice can be "found" in the rules of written law by induction, and that law can be deduced from such concepts; but whatever view they entertain as to what law is, its purpose, and the force which dominates its development, all concede that the rules of the common law, in so far as they have been reduced to writing, were formulated by the court. Consequently, the study of the history of the court will show how these rules were in fact formulated, and will, as I think, demonstrate that they were made by the court in the same way statutes are made by the legislature, or that whatever they may be, they are not rules of natural law.

\footnotetext{
22 Del Vecchio, op. cit. 14-20.

${ }^{23}$ Preface 9 Coke xiv.

"Kohler, op. cit. 5 .
} 
At the beginning of the eleventh century there was no man or body of men either in or out of Britain that was making laws, or even pretending to make laws, for the whole kingdom. While it is true the Church was legislating, it was legislating for the world and not for Britain. At that time all of the courts in England made their own laws. Part of those courts were local assemblies of some or all of the freemen who lived in a particular hundred or shire, township or county, while the others were composed of some or all of the men who lived on a particular estate; but both classes of courts were alike in that they made their own laws. In other words, at the beginning of the eleventh century every court in England-there were hundreds of themmade its own laws. Each court not only made its own laws, but made them, as has already appeared, by vote of the suitors present and voting. There were, therefore, at that time hundreds of laws in force in Britain-so many, in fact, that it is nearly true to say not only that every county, borough and township had its own laws, but that all the large estates had their own laws; and that was literally true in the twelfth century. In fact, the test all courts applied at that time to determine the legality of an act was to inquire whether it was customary, and that, as has already appeared, was but another way of inquiring whether it was one of which the suitors approved. After the kingdoms into which Britain was originally divided had been fused into a single kingdom, and land had become valuable and an object of commerce, this system of local courts was found to be ill-adapted to the needs of the people; and William the Conqueror created a court which in time was to make laws affecting the property rights of every freeholder in Britain, and, for that matter, everyone who lives under the common law.

This court, soon after it was created, aspired to universal jurisdiction; and to bring that about, it made the same use of the doctrine that all land is held of the king that Congress is making of the "commerce clause" of the federal Constitution. The public need that enabled the king's court to accomplish its purpose was that of a uniform system of land-laws, while the public need that is enabling Congress to accomplish its purpose is that of uniform laws in respect to manufacturing and transportation. It is impossible to say just what part feudal ideas played in the evolution of this court, and just what part the ideas of the Roman jurists. It is, perhaps, enough for our purpose 
to say that it was feudal in so far as jurisdiction was concerned, and Roman in so far as the making of laws was concerned. In other words, it differed from all the courts in the kingdom, except the courts of the Church, in the way it made its laws. In all the other courts, as we have seen, the laws were made by the suitors of the court, or as we should say, by those qualified to vote in that precinct. In the king's court, however, the judges made laws in much the same way the Roman emperors made them, or in much the same way the popes were making them at that time. In short, while the king's courts were in some ways like the communal and feudal courts, they differed from them in the way they made laws. They were, however, like all courts of that day in that they were business institutions in the sense that while they did "right and justice," they did it for a price.

Their justice, however, was better than that of most of the local courts, and as they were stronger and better able to enforce their decrees, they naturally attracted, and in the end monopolized, the business. In fact, their business increased so fast that by the end of the twelfth century, their law began to be known as the common law, or as the law common to all freeholders in Britain, to distinguish it from the laws of all the local courts in the kingdom, as well as from the canon and the civil law.

The king's court for a century after its law began to be known as the common law was the only temporal body making laws affecting private rights in all parts of England; but in the last quarter of the thirteenth century, Parliament assumed something like its present form, and engaged in the lawmaking business. In other words, toward the end of the thirteenth century Parliament as we know it was evolved from the king's Wittan, or assembly of wise men, to do for the people of England what the king's courts were doing for the king; but it did not arrogate to itself the sole power to make laws for several centuries after it assumed its present form, as witness the fate of several famous statutes. In fact, that is true to-day; for while the court is accustomed to say that it has no power to make laws, it says in the same breath that it "finds" the rules of the common law; but it is obvious, as it seems to me, that the judges made the rules they formulated in the same way Parliament made statutes; that is, whether or not the judges realized what they were doing, they made the rules of the common law to effectuate the ideals of their royal master in the same way the members of Parliament made statutes to effectuate the will of the people. 
As the power of the people waxed, the power of the king waned, and Parliament gradually took over more and more of the lawmaking business; but it had not assumed exclusive jurisdiction when Britain lost her American colonies. In other words, while the court's power to make laws had been somewhat curtailed in 1776 , it had not been taken away; and at that time, the King's Bench, the Common Pleas and the Exchequer, as well as all the local courts in the kingdom, were making laws as well as enforcing them.

If anyone has any doubts on this point so far as the king's courts are concerned, he should study their history for the middle of the eighteenth century. Such a study will show that the king's courts,-or rather, that Lord Mansfield was elaborating the law of contracts as applied to the transactions of merchants at the time the American states ceased to be British colonies, and just prior to that time. When the people of America separated from Great Britain, they created states to administer their public affairs, and courts to administer their laws. They gave these courts the same powers as the English courts, in so far as their powers were not limited by the Constitution.

The English courts, as we have seen, were legislative bodies and were making laws at that time in the same way they had been making laws ever since they were created in the latter half of the eleventh century; and it would be fair to assume that those who adopted the Constitution intended for the courts they created to legislate in the same way and to the same extent the king's courts were legislating at that time, if it were not for the provisions of the Constitution; for the king's courts had been doing business for nearly seven hundred years, and no one up to that time had even suggested that they should not "find" a rule when no statute or specific rule of the common law was applicable, to determine the rights of the parties in a case they were considering. The constitution of New 'Hampshire - and this is substantially true of all the states-provides that the law shall consist "of all the laws which have heretofore been adopted, used, and approved in the province, colony or state,"25 together with such laws "not repugnant or contrary to this constitution" ${ }^{28}$ as the legislature may from time to time enact. All rules, therefore, that can be deduced from acts of Parliament and of the pro-

${ }^{2}$ Const., Part 2, Art. 89 (90).

* Ibid., Art. 5. 
vincial legislature enacted before $\mathbf{I 7 7 6}$, or from the reports of cases decided before that time, are in force as laws by virtue of this provision of the constitution. Such rules, however, constitute but a very small part of the rules of the common law, as that term is understood and applied by the courts. In other words, most of the rules which are applied by the courts to determine the rights of the parties cannot be deduced from this provision of the constitution or from the acts of the legislature, but have either been made by or revealed to the court.

It is idle to say that the court does not legislate, that the constitution forbids it; for even a casual reading of the reports will show that it makes rules and applies them to determine the rights of the parties in the same way, if not to the same extent, as the courts of Henry II.

In short, such an examination will show that the court does legislate, if making laws is legislation; and this in the face of its declaration that the constitution forbids it to legislate. As it seems to me, such a course is impolitic and calculated to discredit the court. If it must legislate, it should change front in so far at least as to hold that it is its duty under the constitution to legislate in the same way and to the same extent the English courts were legislating in 1776 ; but whatever it does, it should not attempt to look in both directions at the same time. It should either cease to legislate, or cease to declare that the constitution forbids it to legislate; for it is not true to-day, as it was when Glanvil, Bracton, Coke and Blackstone were elaborating the law, that most people think laws are parts of creation, or that the court can "find" specific rules which will work exact justice between man and man not only in the case it is considering, but in any case that may hereafter arise in which a person is injured or damaged by a similar act. It can neither find such rules in the literature of the common or the civil law, nor evolve them from its inner consciousness, if laws are intended to effectuate public ideals; for such ideals are emergent facts incident to the evolution of every community, and everyone will, I think, agree that that is not a logical process. ${ }^{27}$ Although it may be true that even fifty years ago almost everyone believed that the court "found" the rules of the common law, that is not true to-day. In fact, the number of those who refuse to take the

${ }^{2 \pi}$ Cavanaugh v. Boston \& M. R. R. (I9II) 76 N. H. 68, 72, 79 Atl. 694, 696. 
court seriously when it speaks of "deciding a case on principle," or of "finding" a rule of law, is constantly increasing. In fact, there are many who think that the rules courts formulate are the result of reactions on the minds of the judges in the same way statutes are the results of reactions on the minds of the legislators. While it is true that the court makes the rules it formulates, or that they are the result of reactions on the minds of the judges, it is not true that the force which reacts is the same as the one that reacts to produce statutes. The latter force is the needs of the community as evidenced by public opinion, while the one which reacts on the minds of the judges to produce the rules of the common law is composed of public opinion and various superstitions that have come down to them from the days of Coke and Blackstone. One of these is the theory that what the court says in a given case is not so much the reason it gives for deciding as it does in that case, as rules to be followed in all cases; another superstition that contributes is the court's belief that it is powerless to change one of its rules even when it works manifest injustice. Another is the tradition that the rules it formulates are not products of human experience, but exist separate and apart from experience and are revealed to it; or that what it does when it formulates a rule is not to make but to "find" it; in other words, the court's belief that when it formulates a new rule it is doing what Newton did when he formulated the law of gravity. However irrational this theory may be, it has contributed in the past, and to a degree continues to contribute, to the difficulty in understanding what the rules of the common law are. It may be and probably is true that this belief is gradually fading away, for the court will now permit the legislature to make any reasonable changes in the law, ${ }^{28}$ while only a few years ago it would not hesitate to override a statute ${ }^{29}$ or even a provision of the constitution which conflicted with its views of what the law should be. ${ }^{30}$

The court's change of heart has not, however, proceeded far enough to remedy all the evils peculiar to judicial legislation; for at the present time when a new question arises, it is governed more in framing a rule to decide it by what Glanvil,

${ }^{25}$ Carter v. Craig (19I4) 77 N. H. 200, 90 Atl. 598; State v. Prince (rgr5) 77 N. H. 58r, 94 Atl. 966.

${ }^{20}$ Phillips Exeter Academy v. Exeter (1878) 58 N. H. 306, 42 Am. Rep. 589.

${ }^{\circ}$ State v. U. S. \& Canada Express Co. (I880) 60 N. H. 219. 
Bracton, Coke, or Blackstone may have said in respect to a somewhat similar matter, than by a consideration of the results it will produce; that is, by a consideration of whether these results will probably be just as the ordinary man understands justice; while it is too plain for argument that that is the test which should be applied to determine whether a law is just, if laws are intended to effectuate public ideals. ${ }^{31}$

Just what part public opinion plays in formulating the rules of the common law' is very difficult to say. It is the final test with many judges, or what a judge has in mind when he says that a particular rule does not apply because of the results it would produce. It is obvious that it dominates the minds of all judges to a greater or less extent; for whenever the results a rule produces are usually unjust as the ordinary man understands justice, the court will find a way of distinguishing the case it is considering from the one it was considering when the rule was announced. In other words, the court will overrule the rule while professing to follow it..32

It is, therefore, in a sense true that public opinion is the final arbiter of right and wrong in so far as the rules of the common law are concerned, as well as in the case of statutes. The practical objection to judicial legislation, therefore, is not so much the fact the constitution forbids it, as that the public opinion the judge-made rules reflect is that of yesterday rather than that of to-day.

The court's failure to realize these facts not only has excited, but must necessarily continue to excite, criticism; for public opinion is not only constantly changing, but the changes take place more quickly and at more different points with each succeeding century. In other words, the number of ideals that break down, as well as the number of new ideals that are evolved in a given time, are constantly increasing to keep pace with the changes that take place in education, industrial conditions and humanitarian ideals. The study of history is all that is necessary to realize these facts. That will show that for several centuries after our Anglo-Saxon ancestors came to Britain, their ordinary occupations were piracy, driving their neighbors' cattle and killing those who disagreed with them or had anything they wanted.

\footnotetext{
${ }^{31}$ Cavanaugh v. Boston \& M. R. R. (I9II) 76 N. H. 68, 72, 79 Atl. 694, 696.

${ }^{* 3}$ Frye v. Hubbell (I907) 74 N. H. 358, 68 At1. 325 .
} 
If piracy was not recognized as a perfectly legitimate business,

' it was at least tolerated until long after the middle of the sixteenth century.

In fact, that was essentially true until after the middle of the nineteenth century, for it was 1856 when England and France, and 1898 when the United States, finally refused to recognize the right of a nation to license individuals to make war on the commerce of its enemies. Driving their neighbors' cattle and murder are still the ordinary occupation of those inhabiting a large part of Mexico, and that was true but a few years ago of the Panhandle, New Mexico, Arizona and the Indian Territory. In fact, it is nearly true to say that in the past there was a time when many, perhaps most, of the things we consider as right and just, if not looked on as wrong, were not thought of as essential, and when most of the things we think of with horror were considered as right and just-many of them, in fact, as absolutely essential to the salvation of the race. For example, civilized Rome crucified Christians for nearly two centuries. Christian Rome burned heretics for a much longer period, and our ancestors in the sixteenth, seventeenth and eighteenth centuries were accustomed to hang Catholics, Quakers, and witches. To come down to more modern times, it was a crime in at least one state as late as the middle of the nineteenth century to teach a servant to read, while now it is a crime in some states to employ one who cannot read.

Since natural law is a will-o'-the-wisp, or since there is no objective standard of justice other than public opinion, and since that is constantly changing, the question that must be decided is what the court should do when a new question arises; for history teaches, if it teaches anything, that courts are to do justice as well when there are no specific rules applicable as when there are such rules. In other words, history shows that there were judgments, not before public ideals were evolved, but long before specific rules intended to effectuate them were formulated. The question, therefore, is not whether the court shall do justice in all cases, but how it shall settle disputes when no specific rule is applicable. In short, the question is whether the court shall legislate in such cases as our Norman ancestors were accustomed to do, or whether it shall decide them as questions of fact as our Celtic-Anglo-Saxon ancestors were accustomed to do; that is, by inquiring whether the average man would have done the act complained of. As a practical proposi- 
tion, it probably makes little if any difference which of these courses the court pursues, if it remembers that an act which was right and just yesterday may not be reasonable to-day, and that if it is right to-day, it may not be to-morrow; in other words, if the court remembers that it is not true that the law of yesterday was, and that the law of to-morrow will be, the same as that of to-day, except in the sense a person's body is the same to-day that it was yesterday and will be to-morrow. The cells, the organism of which the body is composed, are never twice the same. When one has served its purpose another is substituted for it, and in time nothing is left of the original body. Notwithstanding these changes, the body, in so far as it is considered as a whole, is always the same, for the new cells perform substantially the same office as those for which they were substituted. So with the law; the special rules intended to apply the general rule to specific situations are constantly changing, but notwithstanding these changes, the law as a whole always consists of the general rule and a more or less complete body of special rules intended to apply the general rule to specific situations; and in this sense, it is true that the law never has changed and never will change; but it is equally true that the law is constantly changing. The ideal of an individual gradually develops into a public ideal, and then as gradually looses its hold on the public; and when that happens, rules intended to effectuate it cease to have any office to perform even though they remain as parts of the law. Their position is like that of a dead limb. The limb remains a part of the tree until it drops to the ground or some one takes the trouble to remove it; so a dead rule remains a part of the law until the legislature repeals or the court overrules it.

The truth of the matter seems to be that the rule, it is everyone's duty to do those things and those only the majority approve, never has changed and never will change, but some of the special rules intended to apply this general rule to specific situations are continually changing. When an ideal has served its purpose, rules made to effectuate it have no office to perform. A new ideal is evolved from so much of the old ideal as is vital, and new rules are made to effectuate it. This process of decomposition and recomposition of public ideals and the making of rules to effectuate them is always going on; $;^{33}$ and while the new

${ }^{23}$ Kohler, op. cit. 345 . 
rules, like the old, are intended to effectuate public ideals, they always differ from them. In other words, the rules of every system of law are continually changing to keep pace with the changes in public ideals, but all that can be said of this change is that it is dominated immediately by the needs of humanity; but who can say who or what dominates the evolution of humanity? 